\title{
₹USGS
}

science for a changing world

\section{PUBLICATIONS OF THE WESTERN EARTH SURFACE PROCESSES TEAM 2002}

Compiled by Charles Powell, II and R.W. Graymer

Open-File Report 03-363

2003

This report is preliminary and has not been reviewed for conformity with U.S. Geological Survey editorial standards or with the North American Stratigraphic Code. Any use of trade, firm, or product names is for descriptive purposes only and does not imply endorsement by the U.S. Government

\section{U. S. DEPARTMENT OF THE INTERIOR}

U. S. GEOLOGICAL SURVEY

U. S. Geological Survey, 345 Middlefield Rd., Menlo Park, CA 94025 


\section{INTRODUCTION}

The Western Earth Surface Processes Team (WESPT) of the U.S. Geological Survey (USGS) conducts geologic mapping and related topical earth science studies in the western United States. This work is focused on areas where modern geologic maps and associated earth-science data are needed to address key societal and environmental issues such as ground-water quality, landslides and other potential geologic hazards, and land-use decisions. Areas of primary emphasis in 2001 included southern California, the San Francisco Bay region, the Pacific Northwest, and the Las Vegas urban corridor. The team has its headquarters in Menlo Park, California, and maintains smaller field offices at several other locations in the western United States.

The results of research conducted by the WESPT are released to the public as a variety of databases, maps, text reports, and abstracts, both through the internal publication system of the USGS and in diverse external publications such as scientific journals and books. This report lists publications of the WESPT released in 2002 as well as additional 1998 and 2001 publications that were not included in the previous list (USGS Open-File Report 00-215, USGS Open-File Report 01-198, and USGS Open-File Report 02-269). Most of the publications listed were authored or coauthored by WESPT staff. The list also includes some publications authored by non-USGS cooperators with the WESPT, as well as some authored by USGS staff outside the WESPT in cooperation with WESPT projects.

Several of the publications listed are available on the World Wide Web; for these, URL addresses are provided. Many of these web publications are USGS open-file reports that contain large digital databases of geologic map and related information.

Information on ordering USGS publications can be found on the World Wide Web at http://www.usgs.gov/pubprod/, or by calling 1-888-ASK-USGS. The U.S. Geological Survey’s web server for geologic information in the western United States is located at http://geology.wr.usgs.gov. More information is available about the WESPT is available on-line at http://geology.wr.usgs.gov/wgmt. 


\section{ADDITIONAL 1998 PUBLICATIONS}

1. Beyer, L. A., and McCulloh, T. H., 1998, Bulk densities and porosities of Cenozoic and Cretaceous and older basement rocks, Los Angeles basin, California, determined from measurements of core samples: U. S. Geological Survey Open-File Report 98-788, 197 p., http://geopubs.wr.usgs.gov/open-file/of98-788.

\section{ADDITIONAL 2001 PUBLICATIONS}

1. Bird, K.J., 2001, Alaska: a twenty-first century petroleum province, in Downey, M.W., Threet, J.C., and Morgan, W.A., eds., Petroleum provinces of the twenty-first century: American Association of Petroleum Geologists Memoir 74, p. 137-165.

2. Blakely, R.J., Madin, I.P., Stephenson, W.J., and Popowski, T., 2001, The Canby-Molalla fault, Oregon [abs.]: EOS, Transactions of the American Geophysical Union, v. 82, p. F856.

3. Blakely, R.J., Wells, R.E., and Weaver, C.S., and Meagher, K.L., 2001, Cascadia earthquakes and forearc blocks [abs.]: Seismological Research Letters, v. 72, no. 2, p. 238.

4. Langenheim, V.E., Grow, J.A., Jachens, R.C., Dixon, G.C., Miller, J.J., Lundstrom, S.C., and Page, W.R., 2001, Basin configuration beneath Las Vegas Valley, Nevada: implications for seismic hazard evaluation [abs.], in Luke, B.A., Jacobsen, E.A., and Werle, J.L., eds., Proceedings of the 36th symposium of Engineering geology and geotechnical engineering; Soil and water issues for the arid West: Proceedings of the Symposium on Engineering Geology and Geotechnical Engineering, v. 36, p.755-764

5. $\quad$ Pike, R.J., Graymer, R.W., Roberts, S., Kalman, N.B., and Sobieszczyk, S., 2001, Map and map database of susceptibility toslope failure by sliding and earthflow in the Oakland area, California: U.S. Geological Survey Miscellaneous Investigations Series Map MF-2385, 37 p., scale 1:50,000, http://geopubs.wr.usgs.gov/map-mf/mf2385.

6. Stevens, C.H., Stone, P., and Ritter, S.M., 2001, Conodont and fusulinid biostratigraphy and history of the Pennsylvanian to Lower Permian Keeler Basin, east-central California: Brigham Young University Geology Studies, v. 46, p. 99-142.

7. Wells, R.E., and Simpson, R.W., 2001, Microplate motion of the Cascadia forearc and implications for subduction deformation: Earth Planets Space, v. 53, p. 275-283.

\section{PUBLICATIONS}

1. Barnett, E.A., Weaver, C.S., Haugerud, R.A., Ballantyne, D.B., Wang, Y., Wang, Z., Madin, I.P., Wells, R.E., Darienzo, M., and Meagher, K.L., 2002, Lifelines and earthquake hazards along the Interstate 5 urban corridor: Cottage Grove, Oregon, to Vancouver, B.C. [abs.]: Eos, Transactions American Geophysical Union, v. 83, no. 47, p. F1082, abstract S22B-1033. 
2. Barton, K.E., Howell, D.G., and Vigil, J.F., 2002, The North America tapestry of time and terrain [abs.]: Abstracts with Programs, Geological Society of America, v. 34, no. 6, p. 494.

3. Bemis, B.L., Goss, H.V., Yurkovich, E.S., Perron, T.J., and Howell, D.G., 2002, HAZPAC; an interactive map of Pacific Rim natural hazards, population, and infrastructure: U.S. Geological Survey Digital Data Series, DDS-0076, 1 CD-ROM.

4. Billingsley, G.H., Block, D.L., and Felger, T.J., 2002, Surficial geologic map of the Loop and Durid Arch quadrangles, Canyonlands National park, Utah: U.S. Geological Survey Miscellaneous Field Studies MF-2411, 7 p., scale 1:24,000, http://geopubs.wr.usgs.gov/map-mf/mf2411.

5. Billingsley, G.H., Priest, S.S., and Dudash, S.L., 2002, Geologic map of Clayhole Wash and vicinity, Mohave County, northwestern Arizona: U.S. Geological Survey Miscellaneous Field Studies Map, 2394, 21 p., scale 1:31,680, http://geopubs.wr.usgs.gov/map-mf/mf2394.

6. Billingsley, G.H., Wellmeyer, J.L., Harr, M., and Priest, S.S., 2002, Geologic map of the Hidden Hills and vicinity, Mohave County, northwestern Arizona: U.S. Geological Survey Miscellaneous Field Studies Map MF-2387, 23 p., scale 1:31,680, http://geopubs.wr.usgs.gov/map-mf/mf2387.

7. Bindeman, I.N., Vinogradov, V.I., Valley, J.W., Wooden, J.L., Natal'in, B.A., 2002, Archean protolith and accretion of crust in Kamchatka; SHRIMP dating of zircons from Sredinny and Ganal massifs: Journal of Geology, v. 110, no. 3, p. 271-289.

8. Bird, K.J., 2002, Estimates of undiscovered natural gas volumes, onshore North Slope; a retrospective [abs.]: American Association of Petroleum Geologists Bulletin, v. 86, no. 6, p. 1136.

9. Bird, K.J., 2002, Oil and gas potential of the National Petroleum Reserve, Alaska [abs.]: American Association of Petroleum Geologists Bulletin, v. 86, no. 6, p. 1136-1137.

10. Bird, K.J., and Houseknecht, D.W., 2002, Petroleum resource assessment of the National Petroleum Reserve - Alaska 2002: U.S. Geological Survey Fact Sheet FS-045-02, 6 p., http://geopubs.wr.usgs.gov/fact-sheet/fs045-02.

11. Bird, K.J., and Houseknecht, D.W., 2002, U.S. Geological Survey 2002 petroleum resource assessment of the National Petroleum Reserve in Alaska (NPRA): play maps and technically recoverable resource estimates: U.S. Geological Survey Open-File Report 02207, 18 p., http://geopubs.wr.usgs.gov/open-file/of02-207.

12. Blake, M.C., Jr., Graymer, R.W., and Stamski, R.E., 2002, Digital geologic map and map database of western Sonoma, northernmost Marin, and southernmost Mendocino Counties, California: U.S. Geological Survey Miscellaneous Field Studies Map MF-2402, 29 p., scale 1:100,000, http://geopubs.wr.usgs.gov/map-mf/mf2403. 
13. Blakely, R.J., Brocher, T.M., and Wells, R.E., 2002, Cascadia gravity and magnetic anomalies delineate hydrated forearc mantle [abs.]: Eos, Transactions American Geophysical Union, v. 83, no. 47, p. F1073.

14. Blakely, R.J.,and Johnson, S.Y., 2002, Aeromagnetic anomalies in earthquake hazard investigations: an example from the Canadian-U.S. border: U.S. Geological Survey OpenFile Report 02-400: p. 8-9.

15. Blakely, R.J., Madin, I.P., Stephenson, W.J., and Popowski, T., 2002, The Canby-Molalla fault, Oregon [abs.]: Geological Society of America Abstracts with Programs, v. 34, no. 5, p. A107.

16. Blakely, R.J., and Wells, R.E., New aeromagnetic data from the Pacific Northwest illuminate forearc geology and earthquake hazards [abs.]: Geological Society of America Abstracts with Programs, v. 34, no. 6, p. 387.

17. Blakely, R.J., Wells, R.E., Weaver, C.S., and Johnson, S.Y., 2002, Location, structure, and seismicity of the Seattle fault zone, Washington: Evidence from aeromagnetic anomalies, geologic mapping, and seismic-reflection data: Geological Society of America Bulletin, v. 114, no. 2, p. 169-177.

18. Blakely, R.J., Wells, R.E., Weaver, C.S., and Meagher, K., 2002, The bump and grind of Cascadia forrearc blocks: evidence from gravity and magnetic anomalies [abs.]: Geological Society of America Abstracts with Programs, v. 34, no. 5, p. A33.

19. Blodgett, R.B., and Bird, K.J., 2002, Megafossil biostratigraphy and t-r cycles of the Shublik Formation in the Phoenix well, Northern Alaska [abs.]: American Association of Petroleum Geologists Bulletin, v. 86, no. 6, p. 1137.

20. Bohannon, Robert and Howard, Keith, 2002, Colorado River incision in relation to groundwater flow systems in the southern Great Basin and Arizona: Geological Society of America Abstracts with Programs, v.34, no. 6, p. 395.

21. Brocher, T.M., Parsons, T., and Blakely, R.J., 2002, Three-dimensional upper crustal structure in Puget Lowland, Washington, incorporating Bouguer gravity to enhance seismic traveltime tomography [abs.]: Seismological Research Letters, v. 73, no. 2, p. 256.

22. Brocher, T.M., Parsons, T., and Blakely, R.J., 2002, A simple algorithm for sequentially incorporating Bouguer travity to enhance seismic traveltime tomography: applications to the upper crustal structure in Puget Lowland, Washington [abs.]: Geological Society of America Abstracts with Programs, v. 34, no. 5, p. A32.

23. Bren, A., Hammarstrom, J., Morton, D.M., Priemo, W., and Snee, L., 2002, Plutonic and metamorphic rocks, northern Peninsular Ranges Batholith, southern CA - structural and 
uplift history based on new geobarometric and isotopic data [abs.]: Geological Society of America Abstracts with Programs, v. 34, no. 6, p. 124.

24. Byerly, G.R., Lowe, D.R., Wooden, J.L., and Xie, X., 2002, An Archean impact layer from the Pilbara and Kaapvaal cratons: Science, v. 297, no. 5585, p. 1325-1327.

25. Catchings, R.D., Goldman, M.R., Gandhok, G., and Langenheim, V.E., 2002, Near-surface faults and structure of the western Santa Clara Valley, California, as seen from high resolution seismic reflection and refraction images [abs.]: Eos, Transactions American Geophysical Union, v. 83, no. 47, p. F1027.

26. Clausen, B.L., Morton, D.M., Kistler, R.W., 2002, Additional chemical trends across the northern Peninsular Ranges, southern California [abs.]: Geological Society of America Abstracts with Programs, v. 34, no. 6, p. 125.

27. Cook, H.E., Alexeiev, D.V., Mikolaichuk, A.V., Dzhenchuraeva, A.V., and Corboy, J.C., 2002, Development of an isolated carbonate platform from an underlying attached platform: a newly discovered Devonian-Carboniferous carbonate platform in the Tian Shan Mountains of Kyrgyzstan [abs.]: 2002 AAPG Annual Convention, v. 11, p. A34.

28. Cook, H.E., Zhemchuzhnikov, V.G., Zempolich, W.G., Lehmann, P.J., Buvtyshkin,V.M. , Zhaimina, V.Ya., Kotova, E.A. , Golub, L.Ya., Zorin, A.Ye., Alexeiev, D.V., Viaggi, M., Giovannelli, A., Lapointe, Ph.A., Fretwell, N., Bowman, M., and De Coo, J.C.M., 2002, Evolution of a Devonian and Carboniferous carbonate platform, Bolshoi Karatau, southern Kazakstan: outcrop analogs for coeval carbonate reservoirs in the North Caspian Basin, in Zempolich, W.G., and Cook, H.E., eds., Carbonate systems in the Commonwealth of Independent States (CIS): comparative studies of outcrop and subsurface oil and gas reservoirs: SEPM (Society for Sedimentary Geology) Special Publication 74, p. 83-124.

29. Cox, B.F., Matti, J.C., King, T., and Morton, D.M., 2002, Neogene strata of southern Santa Rosa Mountains, California, and their significance for tectonic evolution of western Salton Trough [abs.]: Geological Society of America Abstracts with Programs, v. 34, no. 6, p. 124.

30. DeGraaff-Surpless, K., Graham, S.A., Wooden, J.L., McWilliams, M.O., 2002, Detrital zircon provenance analysis of the Great Valley Group, California; evolution of an arcforearc system: Geological Society of America Bulletin, v. 114, no. 12, p. 1564-1580.

31. Dumoulin, J.A., and Bird, K.J., 2002, Lithofacies and stratigraphy of the Lisburne and Etivluk groups in the Lisburne 1 well and adjacent outcrops, central Brooks Range, Alaska [abs.]: American Association of Petroleum Geologists Bulletin, v. 86, no. 6, p. 1142.

32. DuRoss, C.B., Blakely, R.J., and Wells, R.E., 2002, Geologic cross section through the Roseburg 30'x60' quadrangle, Oregon: new constaints from potential field modeling [abs.]: Geological Society of America Abstracts with Programs, v. 34, no. 5, p. 32. 
33. Duval, J.S., Pierce, H.A., Daniels, D.L., Mars, J.C., Webring, M.W., and Hildenbrand, T.G., 2002, Aerial magnetic, electromagnetic, and gamma-ray survey, Berrien County, Michigan: U.S. Geological Survey Open-File Report 02-0117, 1 CD-ROM.

34. Eppes, M.C., McFadden, L.D., Matti, J., and Powell, R., 2002, Influence of soil development on the geomorphic evolution of landscapes; an example from the Transverse Ranges of California: Geology, v. 30, no. 3, p. 195-198.

35. Evarts, R.C., 2002, Geologic map of the Deer Island Quadrangle, Columbia County, Oregon and Cowlitz County, Washington: U.S. Geological Survey Miscellaneous Field Studies Map, MF-2392, 45 p., scale 1:24,000, http://geopubs.wr.usgs.gov/map-mf/mf2392.

36. Evarts, R.C., Hagstrum, J.T., Blakely, R.J., Fleck, R.J., Block, J.L., and Dinterman, P.A., 2002, Complex right-lateral faulting at the northern end of the Portland basin: geologic, aeromagnetice, and paleomagnetic evidence [abs.]: Geological Society of America Abstracts with Programs, v. 34, no. 5, p. 33.

37. Fisher, M.A., Normark, W.R., Langenheim, V.E., Sliter, R., Calvert, A., Sorlien, C., and Nicholson, C., 2002, Marine geology of the San Pedro continental shelf region and initial results from seismic relfection data obtained in San Pedro Channel, 2002 [abs.]: 2002 SCEC Annual Meeting Proceedings and Abstracts, p. 69.

38. Fisher, M.A., Normark, W.R., Langenheim, V.E., Sliter, R., Calvert, A., Sorlien, C., Nicholson, C., 2002, Marine geology of the San Pedro continental shelf region and initial results from seismic reflection data obtained in Santa Barbara Channel [abs.]: Eos, Transactions American Geophysical Union, v. 83, no. 47, p. F1315.

39. Fleck, R.J., Criss, R.E., Eaton, G.F., Cleland, R.W., Wavra, C.S., and Bond, W.D., 2002, Age and origin of base and precious metal veins of the Coeur d'Alene mining district, Idaho: Economic Geology and the Bulletin of the Society of Economic Geologists, v. 97, no. 1, p. 23-42.

40. Fleck, R.J., Evarts, R.C., Hagstrum, J.T., and Valentine, M.J., 2002, The Boring volcanic field of the Portland, Oregon area: geochronology and neotectonic significance [abs.]: Geological Society of America Abstracts with Programs, v. 34, no. 5, p. 33-34.

41. Frost, G.M., Barnes, D.F., and Stanley, R.G., 2002, Geologic and isostatic map of the Nenana Basin area, central Alaska: U.S. Geological Survey, Geologic Investigations Series I-2543, 16 p., scale 1:250,000, http://geopubs.wr.usgs.gov/i-map/i2543.

42. Fuis, G.F., Langenheim, V.E., Howard, K.A., Catchings, R.D., Okaya, D.A., Clayton, R.W., and Nicholson, C., 2002, Targets for Earthscope (USArray) in southern California [abs.]: Eos, Transactions American Geophysical Union, v. 83, no. 47, p. F1310.

43. Giliespie, A.J., Jayko, A.S., and Tompson, R.A., 2002, Estimate of Plio-Pleistocene dip-slip rates using offset flood basalts in the northern Panamint Range and Darwin Plateau, 
California [abs.]: Eos, Transactions, American Geophysical Union, v. 83, no. 47, p. 13131314.

44. Glen, J.M.G., and Ponce, D.A., 2002, Large-scale fractures related to inception of the Yellowstone Hotspot: Geology, v. 30, no. 7, p. 647-650.

45. Glen, J.M.G., Pellerin, L., Schmidt, J.M., Sampson, J.A., Morin, R., and Sanger, E. , 2002, Geophysical investigations related to the mineral potential of southcentral AK: a summary of results from the Talkeetna Mountains Transect project [abs.]: Alaska Miners Meeting, November 2002, Anchorage, AK, p. 11.

46. Glen, J.M.G., Schmidt, J., Nelson, S., and Morin, R., 2002, Gravity and magnetic studies of the Talkeetna Mountains and their implications for the Jurassic to recent evolution of structures and tectonics in southern Alaska [abs.]: Geological Society of America Abstracts with Programs, v. 35, no. 5, p. A73.

47. Glen, J., Nomade, S., Lyons, J., Mundil, kr., Metcalfe, I., and Renne, P.R., 2002, Magnetostratigraphy of Permian-Triassic marine sediments from Shangsi, Sichuan Province, China [abs.]: Geological Society of America Abstracts with Programs, v. 34, no. 6, p. 136.

48. Godfrey, N.J., Fuis, G.S., Langenheim, V.E., Okaya, D.A., and Brocher, T.M., 2002, Lower-crustal deformation beneath the central Transverse Ranges, southern California: results from the Los Angeles Region Seismic Experiment: Journal of Geophyscial Research, v. 107, no. B7, p. ETG 8-1 to ETG 8-19.

49. Gray, C.H., Jr., Morton, D.M., Weber, F.H., Jr., Bovard, K.R., O'Brien, T, 2002, Geologic map of the Corona South 7.5' quadrangle, Riverside and Orange counties, California: U.S. Geological Survey Open-File Report 02-21, 19 p., scale 1:24,000, http://geopubs.wr.usgs.gov/open-file/of02-021.

50. Graymer, R.W., Jones, D.L., and Brabb, E.E., 2002, Geologic map and map database of most of Solano County and parts of Napa, Marin, Contra Costa, San Joaquin, Sacramento, Yolo, and Sonoma Counties, California: U.S. Geological Survey Miscellaneous Field Studies Map MF-2403, 30 p., scale 1:100,000, http://geopubs.wr.usgs.gov/map-mf/mf2403.

51. Graymer, R.W., Sarna-Wojcicki, A.M., Walker, J.P., McLaughlin, R.J., Fleck, R.J., 2002, Controls on timing and amount of right-lateral offset on the East Bay fault system, San Francisco Bay region, California: Geological Society of America Bulletin, v. 114, no. 12, p. 1471-1479.

52. Hagstrum, J., 2002, Was the Cretaceous-Tertiary transition initiated by a large bolide impact in the proto-Pacific Ocean prior to that near Chicxulub on the Yucatan Pennsula? [abs.]: Geological Society of America Abstracts with Programs, v. 34, no. 5, p. A42. 
53. Hagstrum, J.T., and Abbott, D., 2002, Evidence for a large bolide impact in the ProtoPacific Ocean preceeding the Chicxulub Impact by about 2 million years [abs.]: Eos, Transactions American Geophysical Union, v. 83, no. 47, p. F797.

54. Hagstrum, J.T., Booth, D.B., Troost, K.G., Blakely, R.J., 2002, Magnetostratigraphy, paleomagnetic correlation, and deformation of Pleistocene deposits in the south central Puget Lowland, Washington [abs.]: Journal of Geophysical Research, B, Solid Earth and Planets, v. 107, no. B4, p. EPM 6-1 - EPM 6-13.

55. Hagstrum, J.T., and Champion, D.E., 2002, A Holocene paleosecular variation record from 14-C-dated volcanic rocks in western North America: Journal of Geophyscial Research, v. 107, no. B1, p. EMP8-1 - EPM8-14.

56. Hagstrum, J.T., Hoblitt, R.P., Gardner, C.A., and Gray, T.E., 2002, Holocene geomagnetic secular variation recorded by volcanic deposits at Mount St. Helen, Washington: Bulletin of Volcanology, v. 63, no. 8, p. 545-556.

57. Hauksson, E., Fuis, G., Hildenbrand, T., and Ryberg, R., 2002, Comparison of aftershock relocations and velocity models through the vicinities of the 1971 San Fernando and 1984 Northridge earthquakes, California - results from combining LARSE99 reflection and CISN/SCSN/TriNet seismicity data [abs.]: Eos, Transactions American Geophysical Union, v. 83, no. 47, p. F1067.

58. Hayba, D.O., Bird, K.J., and Garrity, C.P., 2002, Subsurface indications of oil and gas in the National Petroleum Reserve, Alaska [abs.]: American Association of Petroleum Geologists Bulletin, v. 86, no. 6, p. 1145.

59. Hayba, D.O., Bird, K.J., and Garrity, C.P., 2002, Subsurface oil and gas indications in and adjacent to the NPRA, in Houseknecht, David W., ed., National Petroleum Reserve-Alaska (NPRA) core images and well data: Digital Data Series, DDS-0075.

60. He, J., Wang, K., and Hereford, R., 2002, Valley-fill alluviation during the Little Ice Age (ca. A.D. 1400-1880), Paria River basin and southern Colorado Plateau, United States: Geological Society of America Bulletin, v. 114, no. 12, p. 1550-1563.

61. He, J., Wang, K., Wells, R.E., Dragert, H., James, T., Hu, Y., Hyndman, R.D., and Mazzoti, S., 2002, 3-D elastic and viscoelastic models of Cascadia interseismic deformation: Eos, Transactions American Geophysical Union, v. 83, no. 47, p. F1082, Abstract \# S22B-1017.

62. Hevesi, J.A., Flint, A.L., Flint, L.E., Bedford, D.R., and Miller, D.M., 2002, Representation of the upper unsaturated zone for deterministic watershed modeling in the Mojave Desert region [abs.]: Abstracts with Programs, Geological Society of America, v. 34, no. 6, p. 346.

63. Hildenbrand, T.G., Hinze, W.J., Keller, G.R., Labson, V.F., and Roest, W.R., 2002, Unique U.S. magnetic anomaly database forthcoming [abs.]: Eos, Transactions, American Geophyscial Union, v. 83, no. 49, p. 576. 
64. Hildenbrand, T.G., Mario, A., Bracken, R.E., Hardwick, D., Hinze, W.J., Keller, G.R., Phellips, J., and Walter, R., 2002, Rational and operational plan for a national high-altitude magnetic survey: U.S. Geological Survey Open-File Report 02-366, 22 p., http://geopubs.wr.usgs.gov/open-file/of02-366.

65. Hildenbrand, T.G., McBride, J.H., and Ravat, D., 2002, The Commerce geophysical lineament and its possible relation to Proterozoic igneous complexes and large earthquakes in the central Illinois basin: Seismological Research Letters, v. 73, no. 5, p. 640-659.

66. Hillhouse, J.W., Reichard, E.G., and Ponti, D.J., 2002, Probing the Los Angeles Basin; insights into ground-water resources and earthquake hazards: U.S. Geological Survey Fact Sheet 0086-02, 2 p., http://geopubs.wr.usgs.gov/fact-sheet/fs086-02.

67. Houseknecht, D.W., and Bird, K.J., 2002, The 1998 USGS petroleum resource assessment of the Arctic National Wildlife Refuge 1002 area and adjacent state waters [abs.]: American Association of Petroleum Geologists Bulletin, v. 86, no. 6, p. 1146.

68. Howard, K.A., 2002, Geologic map of the Sheep Hole Mountains 30' x 60' quadrangle, San Bernardino and Riverside Counties, California: U. S. Geological Survey, Miscellaneous Field Studies Map MF-2344, scale 1:100,000, http://geopubs.wr.usgs.gov/map-mf/mf2344.

69. Howard, K.A., 2002, Geologic map of the Battle Ground 7.5' Quadrangle, Clark County, Washington: U.S. Geological Survey Miscellaneous Field Studies Map MF-2395, 18 p., scale 1:24,000, http://geopubs.wr.usgs.gov/map-mf/mf2395/.

70. Howard, K.A., 2002, Ruby Mountains core complex as a guide to Eocene deep crustal structure in the Elko-Carlin region, Nevada [abs.]: Geological Society of America Abstracts with Programs, v. 34, no. 6, p. 83.

71. Howell, G.D., Yurkovich, E.S., Goss, H.V., 2002, Analyzing multi-hazard risk for populations and infrastructure of the Pacific Rim [abs.], in Singer, D.A., ed., Abstracts for the symposium on the Application of neural networks to the earth sciences: U.S. Geological Survey Open-File Report 02-0315, p. 12, http://geopubs.wr.usgs.gov/openfile/of02-315.

72. Huber, N.K., and Eckhardt, W.W., 2002, The story of Devils postpile: Three Rivers, CA, Sequoia Natural History Association, 42 p.

73. Huber, N.K., and Snyder, J.B., 2002, The El Capitan moraine: Yosemite (Yosemite Association), v. 64, no. 1, p. 2-6.

74. Huber, N. K., Phillips, W.H., and Bull, W.B., 2002, The Slide: Yosemite (Yosemite Association), v. 64, no. 3, p. 2-4. 
75. Hudson, T.L., Magoon, L.B., 2002, Tectonic controls on greenhouse gas flux to the Paleogene atmosphere from the Gulf of Alaska accretionary prism: Geology, v. 30, no. 6, p. 547-550.

76. Jachens, R.C., Langenheim, V.E., and Matti, J.C., 2002, Relationship of the 1999 Hector Mine and 1992 Landers Fault ruptures to offsets on Neogene faults and distribution of late Cenozoic basins in the eastern California shear zone, in Rymer, M.J., Langenheim, V.E., Hauksson, E., eds., The Hector Mine, California, earthquake of 16 October 1999: Bulletin of the Seismological Society of America, v. 92, no. 4, p. 1592-1605.

77. Jachens, R.C., Sweetkind, D.S., Langenheim, V.E., Phelps, G.A., and McKee, E.H., 2002, Building hydrogeologic framework models of basins: contributions from geophysicallybased 'elements' [abs.]: Geological Society of America Abstracts with Programs, v. 34, no. 6, p. 394.

78. Jachens, R.C., Wentworth, C.M., Graymer, R.W., McLaughlin, R.J., and Chuang, F.C., 2002, A 40-km-long concealed basin suggests large offset on the Silver Creek fault, Santa Clara Valley, California [abs.]: Geological Society of America Abstracts with Programs, v. 34, no. 3, p. A99.

79. Jachens, R.C., Wentworth, C.M., Graymer, R.W., Chuang, F.C., Simpson, R.W., and McLaughlin, R.J., 2002, The Calaveras fault, northern California: a geophysical perspective on offset and 3-D geometry [abs.]: Eos, Transactions American Geophysical Union, v. 83, no. 47, p. F1312.

80. Jayko, A.S., 2002, Unroofing regional blueschists [abs.]: Geological Society of America Abstracts with Programs, v. 34, no. 5, p. 29-30.

81. Jayko, A.S., Forester, R.M., and Yount, J.C. 2002, Distribution and character of late Pleistocene lacustrine and spring deposits Panamint Valley, California [abs.]: Geological Society of America Abstracts with Programs, v. 34, no. 6, p. 395.

82. Jayko, A.S., and Millar, C.I., 2002, Impacts of climate change on landscapes of the eastern Sierra Nevada and western Great Basin: U.S. Geological Survey Open-File Report 01-202, 35 p., http://geopubs.wr.usgs.gov/open-file/of01-202.

83. Keller, M.A. 2002, Petroleum source potential of the Beaufortian succession of the NPRA and Colville Delta area, North Slope Alaska, based on sonic and resistivity logs [abs.]: American Association of Petroleum Geologists Bulletin, v. 86, no. 6, p. 1148,

84. Keller, M.A., and Evans, K.R., 2002, Hazardous trace elements in petroleum source rocks: http://geology.wr.usgs.gov/wreg/env/index.html (introduction to suite of associated pages).

85. Keller, G.R., and Hildenbrand, T.G., 2002, Upgraded gravity anomaly database of the United States: Society of Exploration Geophysicists, The Leading Edge (Tulsa, OK), v. 21, no. 4, p. 367-369. 
86. Keller, G.R., and Hildenbrand, T.G., 2002, Creation of a data system for gravity measurements: a prototype for geoinformatics [abs.]: Geological Society of America Abstracts with Programs, v. 34, no. 6, p. 225.

87. Keller, G.R., Hildenbrand, T.G., Kucks, R., Roman, D., Hittelman, A.M., 2002, Upgraded gravity anomaly base of the United States: The Leading Edge (Tulsa, OK), v. 21, no. 4, p. 366-367, 387.

88. Kellogg, K.S., Minor, S.A., Stone, P., 2002, Lockwood Valley, California-a result of Pliocene and Quaternary basin contraction between three mountain uplifts [abs.]:

Geological Society of America Abstracts with Programs, v. 34, no. 6, p. 125.

89. King, T., Cox, B.F., Matti, J.C., Powell, C.L., II, Osterman, L.E., and Bybell, L.M., 2002, Previously unreported outcrops of Neogene Imperial Formation in southern Santa Rosa Mountains, California, and implications for tectonic uplift [abs.]: Geological Society of America Abstracts with Programs, v. 34, no. 6, p. 124, http://gsa.confex.com/gsa/2002AM/finalprogram/abstract_44525.htm.

90. Kirby, E., Burbank, D., Jager, J., Reheis, M., and Sarna-Wojcicki, A., 2002, Pleistocene slip rate on the White Mountain fault zone [abs.]: Geological Society of America Abstracts with Programs, v. 34, no. 6, p. 249.

91. Kumar, N., Bird, K.J., Nelson, P.H., Grow, J.A., Evans, K.R., 2002, A digital atlas of hydrocarbon accumulations on the North Slope of Alaska [abs.]: American Association of Petroleum Geologists Bulletin, v. 86, no. 6, p. 1149.

92. Kumar, N., Bird, K.J., Nelson, P.H., Grow, J.A., and Evans, K.R., 2002, A digital atlas of hydrocarbon accumulations within and adjacent to the National Petroleum Reserve - Alaska (NPRA): U.S. Geological Survey Open-File Report 02-71, 81 p., http://geopubs.wr.usgs.gov/open-file/of02-071.

93. Langenheim, V.E., Anderson, M., Jachens, R.C., Matti, J.C., Morton, D.M., and King, T., 2002, 3-D model of subsurface structures between the San Andreas and San Jacinto faults based on gravity and magnetic data [abs.]: 2002 SCEC Annual Meeting Proceedings and Abstracts, p. 88.

94. Langenheim, V.E., Catchings, R.D., McLaughlin, R.J., Jachens, R.C., Wentworth, C.M., Stanley, R.G., and Mankinen, E.A., 2002, An integrated approach to resolving structure associated with the Monte Vista fault zone, southwest Santa Clara Valley, California, using geologic, potential-field, and seismic data [abs.]: Eos, Transactions, American Geophysical Union, v. 83, no. 47, p. F1312.

95. Langenheim, V.E., Hoffmann, J.P., Blasch, K.W., DeWitt, E., and Wirt, L., 2002, Preliminary report on geophysical data in Yavapai County, Arizona: U.S. Geological Survey Open-File Report 02-352, 28 p., http://geopubs.wr.usgs.gov/open-file/of02-352. 
96. Langenheim, V.E., Jachens, R.C., 2002, The Emerson Lake body; a link between the Landers and Hector Mine earthquakes, Southern California, as inferred from gravity and magnetic anomalies, in Rymer, M.J., Langenheim, V.E., Hauksson, E., eds., The Hector Mine, California, earthquake of 16 October 1999: Bulletin of the Seismological Society of America, v. 92, no. 4, p. 1606-1620.

97. Langenheim, V.E., Jachens, R.C., Matti, J.C., Morton, D.M., and Christensen, A.H., 2002, Structure of the San Gorgonio Pass region, southern California, based on analysis of gravity and magnetic data [abs.]: Geological Society of America Abstracts with Programs, v. 34, no. 6, p. 125.

98. Langenheim, V.E., Jachens, R.C., Morton, D.M., and Matti, J.C., 2002, Basins and plutons along the San Jacinto fault zone, San Bernardino Valley to San Jacinto Valley, southern California [abs.]: Geological Society of America Abstracts with Programs, v. 34, no. 5, p. 86.

99. Langenheim, V.E., Page, W.R., Miller, J.J., and Grow, J.A., 2002, Geophysical and geologic constraints on the hydrogeologic framework of the California Wash area, southern Nevada [abs.]: Geological Society of America Abstracts with Programs, v. 34, no. 4, p. A16.

100. Langenheim, V.E., Stiles, S.R., and Jachens, R.C., 2002, Isostatic gravity map of the Monterey 30' x 60' quadrangle and adjacent areas, California: U.S. Geological Survey Open-File Report 02-373, 1:100,000 scale, http://geopubs.wr.usgs.gov/open-file/of02-373.

101. Leech, M.L., Egger, A.E., and Howell, D.G., 2002, A guided inquiry approach to learning the geology of the U.S. [abs.]: Geological Society of America Abstracts with Programs, v. 34, no. 6, p. 344.

102. Macquaker, J.H.S., and Keller, M.A., 2002, Mudstone sedimentation at high latitudes: a petrographic study of the Lower Cretaceous succession from the Mikkelsen bay State \#1 well, Alaska [abs.]: American Association of Petroleum Geologists Bulletin, Pacific Section Meeting, Anchorage, Alaska, v. 86, p. 1150-1151.

103. Macquaker J.H.S. and Keller M.A., 2002, Controls on source rock deposition at high latitudes, in Organic-Carbon burial, climate change and ocean chemistry (MesozoicPaleogene). London, England. Burlington House London: p. 34.

104. Magoon, L.B., Lillis, P.G., Bird, K.J., and Lampe, C., 2002, Petroleum systems of the Alaskan North Slope; a progress report [abs.]: American Association of Petroleum Geologists Bulletin, v. 86, no. 6, p. 1151.

105. Magoon, L.B., Lillis, P.G., Lorenson, T.D., and Stanley, R.G., 2002, Geochemistry of oil and gas samples from the Sargent oil field, California: Open-File Report No. 5, California Department of Conservation, Division of Oil, Gas, and Geothermal resources, 9 p. 
106. Mankinen, E., Lindsley-Griffin, N., and Griffin, J., 2002, Concordant paleolatitudes for Neoproterozoic ophiolitic rocks of the Trinity Complex, Klamath Mountains, California: Journal of Geophyscial Research, v. 107, no. B10, p. 2254.

107. Matti, J.C., Cox, B.F., Morton, D.M., Sharp, R.V., and King, T., 2002, Fault-bounded Neogene sedimentary deposits in the Santa Rosa Mountains, southern California, crustal stretching or transpressional uplift? [abs.]: Geological Society of America Abstracts with Programs, v. 34, no. 6, p. 124.

108. Maughan, L.L., Christiansen, E.H., Best, M.G., Grommé, C.S., Deino, A.L., and Tingey, D.G., 2002, The Oligocene Lund Tuff, Great Basin, USA: a very large volume monotonous intermediate: Journal of Volcanology and Geothermal Research, v. 113, no. 1/2, p. 129157.

109. McBride, J.H., Hildenbrand, T.G., Stephenson, W.J., and Potter, C.J., 2002, Interpreting the earthquake source of the Wabash Valley seismic zone (Illinois, Indiana, and Kentucky) from seismic reflection, gravity, and magnetic intensity data: Seismological Research Letters, v. 73, no. 6, p. 660-686.

110. McCulloh, T.H., Fleck, R.J., Denison, R.E., Beyer, L.A., and Stanley, R.G., 2002, Age and tectonic significance of volcanic rocks in the northern Los Angeles Basin, California: U.S. Geological Survey Professional Paper 1669, 24 p., http://geopubs.wr.usgs.gov/profpaper/pp1669.

111. McLaughlin, R.J., Sarna-Wojcicki, A.M., Fleck, R.J., Graymer, R.W., and Wright, W.H., 2002, Kinematic and geochronologic evidence bearing on partitioning of dextral slip between the Rodgers Creek and Maacama faults, northern San Francisco Bay region, CA [abs.]: Geological Society of America Abstracts with Program, v. 34, no. 5, p. 99.

112. Metcalf, J., Booth, A., Colgean, J., Hourigan, J., Krylov, K., Mattinson, C., McWilliams, M.O., Miller, E., Scherer, H., and Wooden, J., 2002, New constraints on the deformational and metamorphic history of the Funeral Mountains metamorphic core complex, Death Valley, California [abs.]: Geological Society of America Abstracts with Programs, v. 34, no. 6, p. 332.

113. Miller, D.M., Bedford, D.R., Phelps, G., Schmidt, K.M., Lidke, D.M., McMackin, M., and Dudash, S.L., 2002, Surficial geologic map of the Mojave National Preserve, California [abs.]: Geological Society of America Abstracts with Programs, v. 34, no. 6, p. 456.

114. Miller, D.M., Flint, A.L., Flint, L.E., Bedford, D.R., Ellet, K.M., and Blainey, J.B., 2002, Desert soils and geomorphology: implications for moisture budget for plants and susceptibility for erosion [abs.]: Ecological Society of America Annual Meeting, 2002, http://199.245.200.45/pweb/document/?SOCIETY=esa\&YEAR=2002\&ID=8264. 
115. Miller, D.M., and McCarthy, P.T., 2002, Geologic map of the Terrace Mountain West Quadrangle, Box Elder County: Utah Miscellaneous Publication, Utah Geological Survey, O2-3, 13 p., scale 1:24,000.

116. Miller, F.K., Matti, J.C., Brown, H.J., and Powell, R.E., 2002, Digital geologic map of the Fawnskin 7.5’ quadrangle, San Bernardino County, California, version 1.1: U.S. Geological Survey Open-File Report 98-579, 18 p., scale 1:24,000, http://geopubs.wr.usgs.gov/open-file/of98-579, [new revision of 1998 map].

117. Minor, S A., Kellogg, K.S., Stanley, R.G., Stone, P., Powell, C.L., II, Gurrola, L.D., Selting, A.J., and Brandt, T.R., 2002, Preliminary Geologic Map of the Santa Barbara Coastal Plain Area, Santa Barbara County, California, version 1.0: U.S. Geological Survey Open-File Report 02-0136, 22 p., scale 1:24,000, http://greenwood.cr.usgs.gov/pub/open-filereports/ofr-02-0136/.

118. Minor, S.A., Kellogg, K.S., Stanley, R.G., Stone, P., Powell, C.L., II, Gurrola, L.D., Selting, A.J., Brandt, T.R., 2002, New geologic map of the Santa Barbara coastal plain area, southern California, refines understanding of late Cenozoic deformation [abs.]: Geological Society of America Abstracts with Programs, v. 34, no. 6, p. 123.

119. Morin, R.L., and Glen, J.M.G., 2002, Principal facts for 463 gravity stations in the vicinity of Tangle Lakes, East-Central Alaska: U.S. Geological Survey Open-File Report 02-0096, $19 \mathrm{p}$.

120. Morton, D.M., Gray, C.H., Jr., Bovard, K.R., Dawson, M., 2002, Geologic map of the Corona North 7.5' quadrangle, Riverside and San Bernardino counties, California: U.S. Geological Survey Open-File Report 02-022, 18 p., scale 1:24,000, http://geopubs.wr.usgs.gov/open-file/of02-022.

121. Mueller, P.A., Heatherington, A.L., Kelly, D.M., Wooden, J.L., Mogk, D.W., 2002, Paleoproterozoic crust within the Great Falls tectonic zone; implications for the assembly of southern Laurentia: Geology, v. 30, no. 2, p. 127-130.

122. Mull, C.G., Houseknecht, D. W., and Bird, K. J., 2002, New and revised Cretaceous and Tertiary stratigraphic nomenclature, east-central Colville Basin, North Slope, Alaska [abs.]: American Association of Petroleum Geologists Bulletin, v. 86, no. 6, p. 1154.

123. Murphy, L., Fleck, R., and Wooden, J., 2002, Northbrae Rhyolite in the Berkeley Hills, CA: a rock well-misunderstood [abs.]: Geological Society of America Abstracts with Programs, v. 34, no. 6, p. 363.

124. Nelson, A.R., Johnson, S.Y., Wells, R.E., Pezzopane, S.K., Kelsey, H.M., Sherrod, B.L., Bradley, L.-A., Koehler, R.D., Bucknam, R.C., Haugerud, R., and Laprade, W.T., 2002, Field and laboratory data from an earthquake history study of the Toe Jam Hill fault, Bainbridge Island, Washington: U.S. Geological Survey Open-File Report 02-060, 2 oversize sheets, 2 data tables. 
125. Nelson, P.H., Bird, K.J., 2002, Compaction trends and implications for uplift, National Petroleum Reserve, Alaska [abs.]: American Association of Petroleum Geologists Bulletin, v. 86, no. 6, p. 1155.

126. Nomade, S., Glen, J., Lyons, J.J., Mundil, R., Metcalfe, I., and Renne, P.R., 2002, Magnetostratigraphy of the Permian-Triassic paralic sediments from Langzai, Guihzou Province, south-western China [abs.]: Geological Society of America Abstracts with Programs, v. 34, no. 6, p. 508.

127. O'Leary, D.W., Mankinen, E.A., Blakely, R.J., Langenheim, V.E., Ponce, D.A., 2002, Aeromagnetic expression of buried basaltic volcanoes near Yucca Mountain, Nevada: U.S. Geological Survey Open-File Report 02-020, 48 p., http://geopubs.wr.usgs.gov/openfile/of02-020.

128. Pellerin, L., Glen, J., Sanger, E., Sampson, J., and Schmidt, J., 2002, Geophyscial investigations of the Talkeetna Mountains, Alaska [abs.]: 16th International workshop on electromagnetic induction in the earth, Santa Fe, NM, June 16-22, 2002, p. EM 6-36.

129. Phelps, Geoffrey, 2002, Sensitivity analysis of a gravity inversion model in Frenchman Flat Basin: Eos, Transactions American Geophysical Union, v. 83, no. 47, p. 95.

130. Phelps, G., and Graham, S.E., 2002, Preliminary gravity inverstion model of Frenchman Flat Basin, Nevada Test Site, Nevada: U.S. Geological Survey Open-File Report 02-363, 23 p., http://geopubs.wr.usgs.gov/open-file/of02-363.

131. Pike, Richard J., 2002, A bibliography of terrain modeling (Geomorphometry), the quantitative representation of topography - supplement 4.0: U.S. Geological Survey OpenFile Report 02-465, 116 p (paper document), 157 p. (PDF), http://geopubs.wr.usgs.gov/open-file/of02-465.

132. Pike, R.J., and Sobieszczyk, S., 2002, A digital map of susceptibility to large landslides in Santa Clara County, California [abs.]: Eos, Transactions, American Geophyscial Union, v. 83, no. 47, p. F557.

133. Ponce, D.A., and Glen, J.M.G., 2002, Relationship of epithermal gold deposits to largescale fractures in northern Nevada: Economic Geology and the Bulletin of the Society of Economic Geologists, v. 97, no. 1, p. 3-9.

134. Ponce, D.A., Hildenbrand, T.G., and Jachens, R.C., 2002, Gravity and magnetic expression of the San Leandro Gabbro with implications for the geometry and evolution of the Hayward fault zone, northern California [abs.]: Eos, Transactions American Geophysical Union, v. 83, no. 47, p. F1013. 
135. Powell, C.L., II, and Graymer, R.W., 2002, Publications of the Western Earth Surface Processes Team, 2001: U.S. Geological Survey Open-File Report 02-269, 20 p., http://geopubs.wr.usgs.gov/open-file/of02-269.

136. Powell, C.L., II, Stanley, R.G., and Minor, S.A., 2002, Age and paleogeography of the Santa Barbara Formation in the Santa Barbara and Goleta Quadrangles, California, based on mollusks [abs.]: Geological Society of America Abstracts with Programs, v. 34, no. 6, p. 123.

137. Premo, W.R., Morton, D.M., Snee, L.W., Bren, A.M., 2002, SHRIMP U-Pb ages of provenance from detrital Zircon populations of intra-batholithic metasedimentary rocks, N. Peninsular Ranges Batholith, southern California: implications for their tectonic setting [abs.]: Geological Society of America Abstracts with Programs, v. 34, no. 6, p. 124.

138. Quigley, M.C., Karlstrom, K.E., Beard, S., and Bohannon, B. (leaders), 2002, Influence of Proterozoic and Laramide structures on the Miocene extensional strain field, North Virgin Mountains, Nevada/Arizona, in Lund,W.R., Field guide to geologic excursions in southwestern Utah and adjacent areas of Arizona and Nevada: U.S. Geological Survey Open-File Report 02-172, p. 85-104, http://geopubs.wr.usgs.gov/open-file/of02-172.

139. Ravat, D., Kirkham, K., Hildenbrand, T.G., 2002, A source-depth separation filter; using the Euler method on the derivatives of total intensity magnetic anomaly data: The Leading Edge (Tulsa, OK), v. 21, no. 4, p. 360, 362-365.

140. Reheis, M.C., Stine, S., and Sarna-Wojcicki, A.M., 2002, Drainage reversals in Mono Basin during the late Pliocene and Pleistocene: Geological Society of America Bulletin, v. 114, no. 8, p. 991-1006.

141. Renne, P.R., Scott, G.R., Glen, J.M., and Feinberg, J.M., 2002, Oriented inclusions of magnetite in clinopyroxene: source of stable remanent magnetization in gabbros of the Messum Complex, Namibia: Geochemical Geophyscis Geosystems, v. 3, no. 12, 11, p. 1079, doi: 10.10229/2002GC000319.

142. Renne, P., Scott, G., Glen, J., and Feinberg, J., 2002, Oriented inclusions of single domain magnetite in clinopyroxene: source of stable remanent magnetization in gabbros of the early Cretaceous Mussum Complex, Namibia [abs.]: Eos, Transactions, American Geophyscial Union, v. 83, no. 19, Spring meeting, p. S323, Abstract \# GP42A-09.

143. Rymer, M.J., Langenheim, V.E., and Hauksson, E., 2002, The Hector Mine, California, earthquake of 16 October 1999; introduction to the special issue, in Rymer, M.J., Langenheim, V.E., Hauksson, E., eds., The Hector Mine, California, earthquake of 16 October 1999: Bulletin of the Seismological Society of America, v. 92, no. 4, p. 11471153.

144. Sanger, E., Glen, J.M.G., Morin, R., Schmidt, J., and Nelson, S., 2002, Gravity and magnetic modeling of the Nikolani Greenstone in the Amphitheatre syncline, Mt. Hayes 
quadrangle, Alaska [abs.]: Geological Society of America Abstracts with Programs, v. 34, no. 5, p. A73.

145. Sass, J.H., and Priest, S.S., 2002, Distribution of high-temperature (>150 degrees C) geothermal resources in California: U.S. Geological Survey Open-File Report 02-132, 4 p., http://geopubs.wr.usgs.gov/open-file/of02-132.

146. Schmidt, K.M., 2002, Fire, erosion, and reseeding: results from the 1988 " 49 'er Fire” of Grass Valley, CA [abs.]: Geological Society of America Abstracts with Programs, v. 34, no. 6, p. 403.

147. Schmidt, K.M., 2002, Regulating post-fire surface erosion: the relative efficacy of reseeding [abs.]: Geological Society of America Abstracts with Programs, v. 34, no. 6, p. 456.

148. Schmidt, K.M., and Reid, M.E., 2002, Deep-seated landsliding and rock mass strength along the Big Sur, CA coast [abs.]: Eos, Transactions, American Geophysical Union, v. 82, no. 47, p. 551.

149. Schmidt, J.M., Pellerin, L., Glen, J.M.G., Bittenbender, P., Ellis, W.T., and Sampson, J.A., 2002, What lies beneath the Amphitheater Mountains? Geophyscial investigations shed light on the structural setting and PGE-Ni-Cu potential of the Nikolai magmatic system [abs.]: Abstract book, Northwest Miners Association $108^{\text {th }}$ annual meeting, November 2002, p. 17, http://www.nwma.org/pdf/02abstracts.pdf.

150. Stanley, R.G., Jachens, R.C., Lillis, P.G., McLaughlin, R.J., Kvenvolden, K.A., Hostettler, F.D., McDougall, K.A., and Magoon, L.B., 2002, Subsurface and petroleum geology of the southwestern Santa Clara Valley (“Silicon Valley”), California: U.S. Geological Survey Professional Paper 1663, 55 p., http://geopubs.wr.usgs.gov/prof-paper/pp1663.

151. Stanley, R.G., and Troutman, S.M., 2002, Preliminary map of oil and gas occurrences in central Alaska [abs.]: American Association of Petroleum Geologists Bulletin, v. 86, no. 6, p. 1160.

152. Stanley, R.G., and Vedder, J.G., 2002, Geologic mapping of the San Rafael Mtn. Quadrangle, Santa Barbara County, California, reveals an older Camuesa fault [abs.]: Geological Society of America Abstracts with Programs, v. 34, no. 6, p. 126.

153. Stevens, C.H., and Stone, P., 2002, Correlation of Permian and Triassic deformations in the western Great Basin and eastern Sierra Nevada: evidence from the northern Inyo Mountains near Tinemaha Reservoir, east-central California: Geological Society of America Bulletin, v. 114, no. 10, p. 1210-1221.

154. Stoffer, P., 2002, Rocks and geology in the San Francisco Bay region: U.S. Geological Survey Bulletin 2195, 58 p., http://geopubs.wr.usgs.gov/bulletin/b2195. 
155. Stoffer, P., 2002, Field-trip guide to the geology of the Lexington Reservoir and Loma Prieta area in the Santa Cruz Mountains, Santa Clara and Santa Cruz Counties, California: U.S. Geological Survey Open-File Report 02-221, 26 p., http://geopubs.wr.usgs.gov/openfile/of02-221.

156. Stoffer, P.W. and Messina, P., 2002, Field-Trip Guide to the Southeastern Foothills of the Santa Cruz Mountains In Santa Clara County, California: U.S. Geological Survey OpenFile Report 02-121, 27 p., http://geopubs.wr.usgs.gov/open-file/of02-121.

157. Sweetkind, D.S., Faunt, C.C., and Phelps, G., 2002, Uncertainty inherent in geologic data, interpretations and conceptualmodels used in groundwater flow modeling: Eos, Transactions American Geophysical Union, v. 83, no. 47, p. 180.

158. Tabor, R.W., Booth, D. B., and Ford, A. B., 2002, Geologic map of the Sauk River 30- by 60-minute quadrangle: U.S. Geological Survey Miscellaneous Investigations Map I-2539, 67 p., scale 1:100,000.

159. Tabor, R.W., and Haugerud, R.A., 2002, Geologic map of the North Cascades, Washington: progress report on a compliation [abs.]: Geological Society of America Abstracts with Programs, v. 34, no. 5, p. A31.

160. ten Brink, U.S., Molzer, P.C., Fisher, M.A., Blakely, R.J., Bucknam, R.C., Parsons, T., Crosson, R.S., Creager, K.C., 2002, Subsurface geometry and evolution of the Seattle fault zone and the Seattle Basin, Washington: Bulletin of the Seismological Society of America, v. 92 , no. 5 , p. $1737-1753$.

161. Troutman, S.M., and Stanley, R.G., 2002, Map and digital database of sedimentary basins and indications of petroleum in the central Alaska Province: U.S. Geological Survey OpenFile Report 02-483, scale 1:2,500,000, http://geopubs.wr.usgs.gov/open-file/of02-438.

162. Underwood, M., Duddy, I., McLaughlin, R., 2002, History of heating, uplift, and cooling south of the Mendocino trip junction, coastal California [abs.]: Eos, Transactions American Geophysical Union, v. 83, no. 47, p. F1304.

163. Verma, M.K., and Bird, K.J., 2002, Role of reservoir engineering in the assessment of undiscovered oil and gas resources in the National Petroleum Reserve, Alaska (NPRA) [abs.]: American Association of Petroleum Geologists Bulletin, v. 86, no. 6, p. 1161-1162.

164. Vogel, M.B., Jayko, A.S., Wooden, J.L., and Smith, R.S.U., 2002, Quaternary exhumation rate central Panamint Range, California from U-Pb zircon ages [abs.]: Geological Society of America Abstracts with Programs, v. 34, no. 6, p. 249.

165. Wells, R.E., Blakely, R.J., and Sugiyama, Y., 2002, Great slip in great earthquakes occur under forearc basins [abs.]: Seismological Research Letters, v. 73, p. 248. 
166. Wells, R.E., Blakely, R.J., and Sugiyama, Y., 2002, Great slip in great subduction earthquakes occurs under forearc basins [abs.]: Geological Society of America Abstracts with Programs, v. 34, no. 5, p. 36.

167. Wells, R.E., Blakely, R.J., Sugiyama, Y., and Scholl, D., 2002, Coseismic slip beneath forearc basins in great subduction zone earthquakes: implications for the size and mode of rupture on the Cascadia Subduction Zone [abs]: Eos, Transactions American Geophysical Union, v. 83, no. 47, p. F1073.

168. Wells, R.E., Blakely, R.J., and Weaver, C.S., 2002, Cascadia microplate models and withinslab earthquakes, in Kirby, S., Wang, K., and Dunlop S., eds., Intraslab earthquakes in the Cascadia subduction system: Science and Hazards: U.S. Geological Survey Open-File Report 02-328, p. 17-24.

169. Wilshire, H.G., Bedford, D.R., and Coleman, T., 2002, Digital version of “Open-File Report 92-0179: Geologic map of the Cow Cove Quadrangle, San Bernardino County, California”: U.S. Geological Survey Open-File Report 02-274, 27 p., scale 1:24,000, http://geopubs.wr.usgs.gov/open-file/of02-274.

170. Wilshire, H.G., Bedford, D.R., and Coleman, T., 2002, Digital version of 'Open-File Report 92-182: Geologic map of the Marl Mountains Quadrangle, San Bernardino County, California’: U.S. Geological Survey Open-File Report 02-271, 27 p., scale 1:24,000, http://geology.wr.usgs.gov/open-file/of02-271.

171. Wilshire, H.G., Bedford, D.R., and Coleman, T., 2002, Digital version of “Open-File Report 92-181: Geologic map of the Indian Spring Quadrangle, San Bernardino County, California”: U.S. Geological Survey Open-File Report 02-272, 27 p., scale 1:24,000, http://geology.wr.usgs.gov/open-file/of02-272.

172. Wilshire, H.G., Bedford, D.R., Coleman, T., 2002, Digital version of “Open-File Report 92183: Geologic map of the Granite Springs Quadrangle, San Bernardino County, California”: U.S. Geological Survey Open-File Report 02-273, 27 p., scale 1:24,000, http://geology.wr.usgs.gov/open-file/of02-273.

173. Wirt, L., Langenheim, V.E., DeWitt, E., 2002, Geologic framework of aquifer units and ground-water flow paths near the outlet of two southwestern alluvial basins - upper Verde River, Arizona [abs.]: Abstracts with Programs, Geological Society of America, v. 34, no. 6, p. 394.

174. Yokoyama, R., Shirasawa, M., and Pike, R.J., 2002, Visualizing topography by openness - a new application of image processing to digital elevation models: Photogrammetric Engineering and Remote Sensing, v. 68, no. 3, p. 257-265.

175. Zempolich, W.G., and Cook, H.E., eds., 2002, Carbonate systems in the Commonwealth of Independent States (CIS): comparative studies of outcrop and subsurface oil and gas reservoirs: SEPM (Society for Sedimentary Geology) Special Publication 74, 250 p. 
176. Zempolich, W.G., and Cook, H.E., 2002, Introduction: Paleozoic carbonates of the Commonwealth of Independent States (CIS): comparative Studies of outcrop and subsurface oil and gas reservoirs, in Zempolich, W.G., and Cook, H.E., eds., Carbonate systems in the Commonwealth of Independent States (CIS): comparative studies of outcrop and subsurface oil and gas reservoirs: SEPM (Society for Sedimentary Geology) Special Publication 74, p. 1-4.

177. Zempolich, W.G., Cook, H.E., Zhemchuzhnikov, V.G., Zorin, A., Giovannelli, A., Viaggi, M., and Zhaimina, V.Ya., 2002 The role of biotic and abiotic constituents in the development and diagenesis of middle to late Paleozoic carbonate platforms: outcrop and subsurface examples from the C.I.S., in Zempolich, W.G., and Cook, H.E., eds., 2002, Carbonate systems in the Commonwealth of Independent States (CIS): comparative studies of outcrop and subsurface oil and gas reservoirs: SEPM (Society for Sedimentary Geology) Special Publication 74, p. 125-184. 


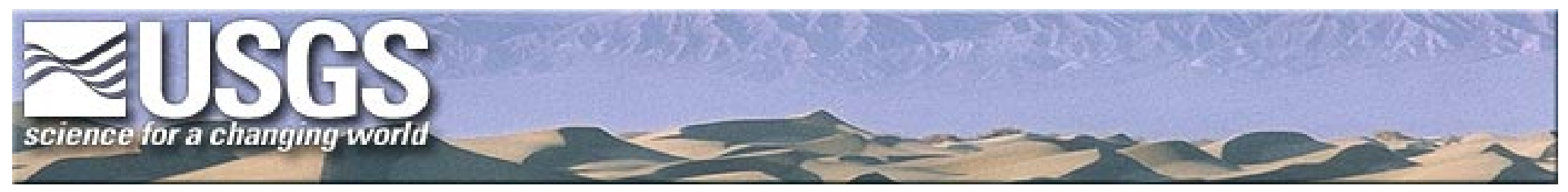

\section{Western Earth Surface Processes Team}

\section{Contact Us}

\section{Team Activities}

Westerm Earth Surface Processes Team Highlights

Southwest Desert Landscapes

Las Vegas Urban Area

Northern California Landslide Working Group

Pacific Northwest Urban Hazards and Geology

San Francisco Bay Region

Southern California Area Mapping Project

Central Death Valley Geologic Framework

Geology of National Parks

Energy Resources

Geophysical Unit of Menlo Park (GUMP)

3D Geology Project

Geochronology Resources

Education

\section{Geologic Information}

Western Earth Surface Processes Team Publications

Find Other Geologic Publications

Using Geologic Maps

Western Region Geologic Information

\section{Team Overview}

The western region of the United States is the most geologically active and varied part of the country. The role of the team is to provide the geologic information required to understand the interactions among humans, plants, animals, air, water, soil, and rock on the Earth's surface region. This information is provided by the publication of a variety of geologic maps and databases, and scientific reports, and by participation in programs designed to improve the understanding of geologic information and the ability to use it for informed decision making. The team is composed of geologists, geophysicists, paleontologists, and support personnel located throughout the western states.

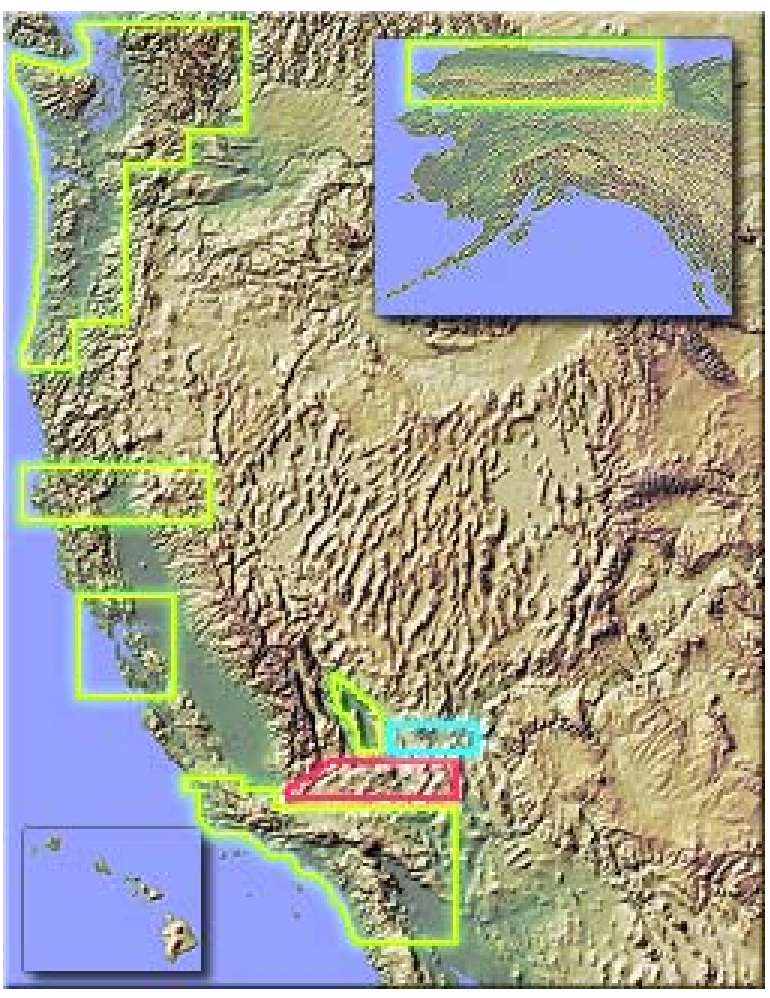

Click on the map above to see information. 


\section{Visit other Earth Surface Processes teams.}

\section{Central Region | Eastern Region}

\section{USGS Home | Biology | Geology | Mapping | Water | Search USGS |}

Privacy statement- - General Disclaimer

Please send comments and suggestions to: pstoffer@usgs.gov, or

see the WESP Team Webmasters page.

The URL of this page is http://geology.wr.usgs.gov/wgmt

Updated: 7 May 2003 